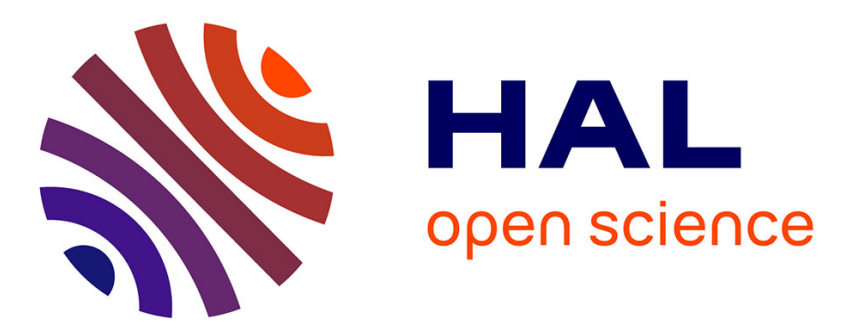

\title{
Deixis and Temporal Subordinators in Pomak (Slavic, Greece) \\ Evangelia Adamou
}

\section{To cite this version:}

Evangelia Adamou. Deixis and Temporal Subordinators in Pomak (Slavic, Greece). Isabelle Bril. Clause-Linking and Clause-Hierarchy: Syntax and Pragmatics, John Benjamins, pp.399-420, 2010, Studies in Language Companion Series 121. hal-00398498

\section{HAL Id: hal-00398498 https://hal.science/hal-00398498}

Submitted on 24 Dec 2009

HAL is a multi-disciplinary open access archive for the deposit and dissemination of scientific research documents, whether they are published or not. The documents may come from teaching and research institutions in France or abroad, or from public or private research centers.
L'archive ouverte pluridisciplinaire $\mathbf{H A L}$, est destinée au dépôt et à la diffusion de documents scientifiques de niveau recherche, publiés ou non, émanant des établissements d'enseignement et de recherche français ou étrangers, des laboratoires publics ou privés. 


\title{
Deixis and Temporal Subordinators \\ in Pomak (Slavic, Greece)
}

\author{
Evangelia Adamou \\ LACITO-CNRS \\ \& Fédération Typologie et Universaux du Langage, FR 2559-CNRS
}

\begin{abstract}
Deixis expressed by three definite articles is a well-known characteristic of the Pomak varieties, given the absence of grammaticalized definite markers in most Slavic languages. In this paper, we present a practically unknown use of deixis in Slavic languages, namely the use of deictic suffixes in the formation of temporal subordinate conjunctions in Pomak. The deictic suffixes in the temporal subordinator indicate the relation of the process to the situation of utterance, and the choice of the deictic suffix depends on the type of event encoded in the clause. The free temporal subordinator indicates absence of anchoring of the event to the speech time. This study is based on first-hand data of a practically undescribed Pomak variety spoken in Greece.
\end{abstract}




\section{Introduction}

In a Pomak variety spoken in Greece, in the Xanthi area, three suffixes specify the location of an entity in relation to the speaker's sphere $(-s-)$, the addressee's sphere $(-t-)$, or away from the speaker and the addressee $(-n-)$. All three suffixes are used in the formation of definite articles and demonstratives (see §3). Two of them, namely -t- and - $n-$, are also used with temporal values when the space and time are different from that of the situation of utterance: $t$ - is no longer used for an entity in the addressee's sphere, but for an entity in a past time relative to the situation of utterance ${ }^{1}$.

Those uncommon uses allow us to understand the equally uncommon uses of those two deictic suffixes that form temporal subordinate conjunctions which anchor the event to the situation of utterance (for the theoretical framework and terminology of this analysis see Culioli 1971, 1978, 1990 and Robert 2006, also §4.2.1). Ag'ato/kug'ato 'when (past)' is used for a past moment in relation to the situation of utterance. $A g^{\prime}$ 'ano/kug'ano 'when, whenever', is employed for future moments in relation to the situation of utterance, as well as for habitual events. Absence of these deictics indicates absence of anchoring to the situation of utterance; $a g^{\prime} a$ 'when (no anchoring)' is thus used in fictional narratives (see $\S 4$ ). Immediate anteriority is expressed by prefixing $l i$ 'immediately, all the time' to the subordinators presented above: $l i$ $g a$ 'as soon as (no anchoring)', li kug'ato 'as soon as (past)' and li kug'ano 'as soon as (future)'. 
Table 1: Semantics and uses of deictic suffixes in Pomak1

\begin{tabular}{|c|c|c|c|c|}
\hline & $-S-$ & $-t-$ & $-n-$ & (no deictic suffix) \\
\hline \multicolumn{5}{|l|}{ Noun } \\
\hline 1) Here \& now & $\begin{array}{l}\text { 1) speaker's } \\
\text { sphere }\end{array}$ & $\begin{array}{l}\text { 1) addressee's } \\
\text { sphere }\end{array}$ & 1) distal & indefinite \\
\hline $\begin{array}{l}\text { 2) Different space } \\
\text { \& time }\end{array}$ & $\mathrm{x}$ & $\begin{array}{l}\text { 2) past moment } \\
\text { in relation to the } \\
\text { situation of } \\
\text { utterance }\end{array}$ & $\begin{array}{l}\text { 2) - future \& habitual in } \\
\text { relation to the situation of } \\
\text { utterance; } \\
\text { - absence of anchoring to } \\
\text { the situation of utterance }\end{array}$ & \\
\hline Subordination & $\mathrm{x}$ & $\begin{array}{l}\text { past moment } \\
\text { in relation to the } \\
\text { situation of } \\
\text { utterance }\end{array}$ & $\begin{array}{l}\text { future or habitual } \\
\text { in relation to the situation } \\
\text { of utterance }\end{array}$ & $\begin{array}{l}\text { - absence of anchoring to } \\
\text { the situation of utterance } \\
\text { - (conditional) }\end{array}$ \\
\hline
\end{tabular}

A tripartite deictic system of definite markers is attested in other South Slavic languages, such as Standard Macedonian, but the constraints of usage are very different from those of Pomak described in this paper (see §3.1.1). Standard Bulgarian makes use of one definite article, based on the -t- suffix, while practically all the other Slavic languages have no grammaticalized definite markers.

As far as the use of deixis in the temporal subordinators is concerned, Pomak holds a special place within the Slavic languages. Among the closest related languages, Macedonian does not make any use of the three deictic suffixes in order to form subordinating conjunctions. Bulgarian, on the other hand, uses the -t- suffix (also used for the definite article) to form a number of subordinators, but those conjunctions do not enter a system of oppositions related to deictics. The data available for the Rhodope dialects in Bulgaria show a similar use of the deictic suffixes in the subordinators as those described in this paper, but no study is available on their precise values and uses. 
Even though the grammaticalization of a definite article is considered to be an areal feature in the Balkans, the extensive use of deixis observed in Pomak temporals cannot be explained through language contact, despite the Pomak speakers' trilingualism with Greek and Turkish.

\section{Pomak: sociolinguistic information}

Pom'atsko 'Pomak' is the name used for the South Slavic variety spoken by Muslim inhabitants of the Rhodope Mountains in Greece (cf. map 1) who often migrated to other cities or countries during the second half of the $20^{\text {th }}$ century. This study ${ }^{2}$ focuses on a Pomak variety spoken in a village of the Xanthi area I will refer to as Pomak $1^{3}$.

The language in the village under study is still transmitted to children, contrary to other traditional Pomak speaking villages in Greece, where a shift to Turkish has been generalized. The majority of the speakers in this village are trilingual. The younger generation, men and women, have learnt Greek and Turkish at school, within the "Minoritariste" primary school educational system provided to the Muslim Minority since the Lausanne Treaty (1923). Elder women are sometimes monolingual or, most frequently, have basic communicational skills in Greek and Turkish (see Adamou and Drettas 2008).

Pomak is often described as a conservative South Slavic group since it has for example preserved a case system, in contrast with the most closely related South Slavic languages that developed an analytical system for those functions. This feature is important since loss of the case system is one of the features distinguishing Bulgarian and Macedonian from Serbian for example.

Naturally, this approach can be questioned given that on other points the system can be described as an innovative one, as for example in the case of the overt expression of deixis 
and its use for the temporal conjunctions described in this paper. Moreover, Pomak also shares some Balkan Sprachbund properties, such as "will” future, subjunctive, dative/genitive merger (observed in the Pomak1 variety), postposed articles, and to some extent evidentiality (see Adamou 2008; for evidentiality as a Balkan feature see Friedman 2004).

The Pomak spoken in Greece has a special interest for the study of South Slavic because it had little contact with modern Bulgarian, standard or dialectal, during the greatest part of the $20^{\text {th }}$ century (except for the few years of Occupation during the Second World War when education in Bulgarian was obligatory), and therefore did not undergo any changes due to standardisation practices, as did the varieties spoken in Bulgaria (Kanevska-Nikolova 2001).

Pomak varieties in Greece are still practically undescribed because, within a context of shift to Turkish, the Pomak language is submitted to political and ideological conflicts that make fieldwork research extremely difficult to conduct. Still, educated Pomak speakers, most often in collaboration with Greek authors, have participated in the publication of dictionaries, grammars, teaching methods for foreigners and other material such as folktales and songs (see Theoharidis 1995, 1996a, 1996b, 1996c, Rogo 2002, Kokkas 2004a, 2004b).

\section{Deixis and noun modification}

The Pomak variety under study has a three-term person-oriented deictic system, the deictic centre being not only the speaker but the addressee as well (see Anderson \& Keenan 1985). Innovating temporal uses also occur for the definite articles and are described in 3.1.2.

\section{Table 2. Deictic suffixes in Pomak1}

\begin{tabular}{ll}
\hline$-s-$ & speaker's sphere; here and now \\
$-t-$ & addressee's sphere; past moment related to the situation of utterance \\
$-n-\quad$ distal (not located in the participants' spheres); future, present moment related to the situation of \\
$\quad$ utterance; no anchoring to the situation of utterance
\end{tabular}


Those three suffixes form the definite articles and the demonstratives presented below (see $\S 3.1 .2$ and $\$ 3.2 .2)$.

\subsection{The definite articles}

\subsubsection{Definite articles in the South Slavic languages}

Definite articles are an exception within the Slavic languages: they have only been grammaticalized in some South Slavic languages (namely Bulgarian, Macedonian and all the non-standardized varieties spoken in Greece), while their grammaticalization in some dialects of North Russia is controversial (see Breu 1994, Kasatkina 2008). In an areal perspective, postposed articles are a well-known Balkan Sprachbund property -shared by Romanian, Aromanian and Meglenoromanian, as well as Albanian- even though their development is probably equally influenced by each language's diachrony as well as by their mutual reinforcement through multilingualism (Asenova 2002).

As is generally admitted, definite articles are grammaticalized from demonstratives (Lyons 1999). In the case of South Slavic, written sources show that, by the $13^{\text {th }}$ century, the postposed Old Church Slavonic ${ }^{4}$ demonstratives were grammaticalized into clitic demonstratives, and then into clitic articles: see Gălăbov (1950), Svane (1961, 1962), Mirčev (1964) or more recently Dimitrova-Vulchanova \& Vulchanov (in press); for a discussion of the status in the modern languages see Elson (1976); for a detailed diachronic model of definiteness in Bulgarian see Mladenova (2007).

The threefold definite article is traditionally considered in the literature as a "conservative" feature (Miletič, Koneski, Cyxun), following the analysis that the whole of South Slavic has gone through a phase of grammaticalization of three definite articles and then developed in some varieties to a single definite, while in others the three definites were maintained. Divergent analyses exist, arguing convincingly that the three-term definites are 
innovations of specific varieties but didn't develop to all the South Slavic languages (Mladenova 2007: 319-325 also citing Velčeva-Bojadžieva and Šaur).

In a synchronic perspective, the use of a one-term or three-term definite article requires a different dialectological analysis than the traditional dialectal classifications of South Slavic in terms of 'Eastern-Western' dialects following the phonetic distribution of the jat. Among the modern South Slavic varieties that have a grammaticalized definite article, the ternary deictic definite system is found in three geographic areas: this is the case of some Macedonian dialects and is the norm for Standard Macedonian (see Table 3); most of the varieties of the Rhodope Mountains (in Bulgaria and Greece), as well as some varieties that are spoken in Eastern Serbia (next to the Bulgarian border).

All the other South Slavic varieties that have developed a definite article are using a one-term system, usually based on the -t- form: this is the case of Standard Bulgarian and Bulgarian dialects ${ }^{5}$, the Eastern Macedonian dialects and the South-West Slavic varieties spoken in Greece (Drettas 1990, Adamou 2006). Some varieties are said to be in an unstable situation, evolving from the ternary to the single term system (Kanevska-Nikolova 2006, and fieldwork notes Adamou 2005-2006 for Evros Pomak2) ${ }^{6}$. The existence of two-fold definite systems is controversial (for a critical analysis see Mladenov 1990).

Furthermore, it is important to note that even among the ternary systems, the parameters and the morphological distribution can differ. It would be interesting to know whether some differences observed are due to different analyses or to effective differences of the systems. For example, Kanevska-Nikolova (2006: 79) describes the Rhodope definite system as what can be named after Anderson \& Keenan's (1985) terminology a distance oriented system (the speaker being its centre, in pragmatic or spatial terms), while in Mladenova (2007: 318) the Rhodope system is clearly described as person-oriented. The most recent descriptions of 
Macedonian also centre its system on the speaker (Minova-Gurkova 1997, Friedman 2002; and for a different analysis Topolinjska 2006):

Table 3. Deictic suffixes in Standard Macedonian's definite articles

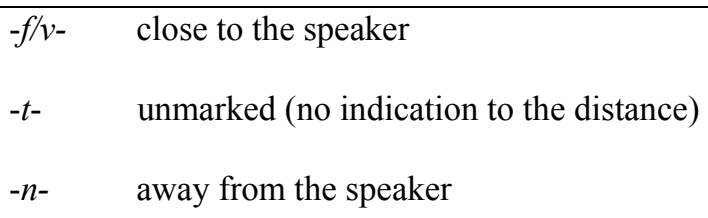

The same split is found in the analyses of OCS demonstratives: for example, in Vaillant (1964: 140) the system appears to be distance-oriented while in Feuillet (1999: 148) it is described as person-oriented. According to Marchello-Nizia (2006) this sort of distinction could indicate different states of the language and is thus important to specify.

\subsubsection{Definites in Pomak1}

The definite article $^{7}$ is suffixed to the noun, the adjective or the tonic possessive pronoun and the possessive adjective. Three deictic suffixes are used in Pomak1 to form definite articles. The choice of the deictic suffix depends on two types of parameters:

1/ For here and now situations the system depends on whether the entity is considered as being part of the speaker's sphere, the addressee's sphere, or none of them. According to Anderson \& Keenan (1985), this type of system is named person-oriented.

Deictic systems are generally described in 'close vs. distant' terms: close to the speaker, close to the addressee, away form the speaker and the addressee. Still, it is broadly admitted that pragmatic parameters generally rule those systems (Levinson 2004). In order to account for those uses, the term 'personal spheres' is preferred here (Bally 1926, MarchelloNizia 2006).

In Pomak1, even though in most cases, the 'sphere' could appear to be spatial, other examples show that the system is determined by pragmatic and discursive criteria as well. The 
objective distance can thus be manipulated according to pragmatic criteria, but such uses will not be developed in detail here.

-s- : 'speaker's sphere'

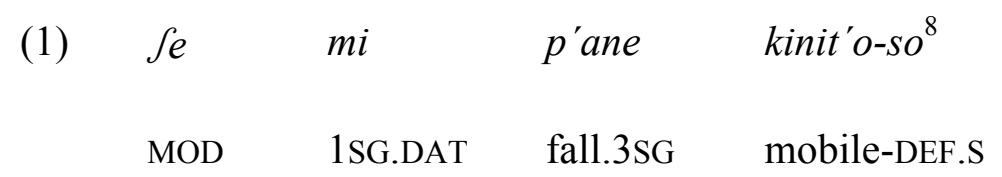

'The mobile phone will fall from me!'

(The speaker has the mobile phone in his pocket) $(\mathrm{S}, \mathrm{M} 1,8, \mathrm{Pmk}, \mathrm{Ell}, \mathrm{Tur})^{9}$

This definite is also used with a strong possessive meaning.

-t- : 'addressee's sphere'

(2) bul'uz-at ti je h'ubaf

t.shirt-DEF.A POSS. $2 \mathrm{SG}$ is. $3 \mathrm{SG}$ nice

'Your t-shirt (your sphere) is nice.'

(The addressee is wearing the t-shirt) (S, F5, 15, Pmk, Ell, Tur)

-n- : 'distal (not located in the participants' spheres)'

The suffix - $n$ - is used for objects that are not included in the participant's spheres.

(3) j'ela nah kap'uje-ne
come.IMP.2SG to doors-DEF.DIST
'Come to the entrance door (elsewhere).' 
(The speaker is out of the house, the addressee is sitting at the balcony, and the entrance door is on the side of the house, away from both and not visible to any of them) (S, M3, 13, Pmk, Ell, Tur)

We should also note that in the variety described here, the deictic system does not seem obsolescent among younger speakers, contrary to other Pomak varieties which tend to reduce it.

2/ When the entities are situated in a different space and time, then the speaker adopts a temporal set of uses of the definite articles. In such cases, only the $-t$ - and $-n$ - articles are concerned, the $-s$ - leading back to a spatial-temporal reading 'here and now'. Therefore, the addressee's $-t$ - article no longer concerns the addressee's sphere but the past, while the $-n$ distal article is used for entities in the future, habitual in relation to the situation of utterance as well as for the situations with no anchoring to the situation of utterance (all 'non past' and 'non here an now' situations):

-n- : 'future moment in relation to the moment of utterance'

$$
\begin{aligned}
& \text { na sf'adba-na Se n'adena-m tferv'en-en } \\
& \text { at wedding-DEF.DIST MOD wear-1SG red-DEF.DIST }
\end{aligned}
$$

'At the wedding I'll wear a red dress.' (Q, F2, 30, Pmk, Ell, Tur)

\section{-t- : 'past moment in relation to the moment of utterance'}

$$
\begin{aligned}
& \text { na } s f^{\prime} a d b a-t a \quad \text { bex } \quad \text { sas } t \text { Serv'en-et fust'an } \\
& \text { at wedding-DEF.LOC.PAS was.1SG with red-DEF.LOC.PAS dress } \\
& \text { 'At the wedding I wore a red dress.' (Q, F2, 30, Pmk, Ell, Tur) }
\end{aligned}
$$




\section{-s- : 'speaker's sphere'}

(6)

$$
\begin{aligned}
& \text { na sf'adba-sa sam / 'ima mn'ogo ins'an } \\
& \text { at wedding-DEF.S am.1SG / is.3SG a,lot people }
\end{aligned}
$$

'I'm at the wedding. There is a lot of people.' (Q, F2, 30, Pmk, Ell, Tur)

\subsection{The demonstratives}

\subsubsection{Demonstratives in the South Slavic languages}

In data available for South Slavic, demonstratives and definite markers do not seem to follow the same development within a variety and certainly not at the same speed. For example, even though the demonstrative system in Pomak1 is a three-term system, used in the same way as the definite system, in other close Pomak varieties (Kokkas 2004a: 22), demonstratives form a twofold system based on a 'close-distant' spatial contrast ${ }^{10}$, while the definite articles form a three-term person-oriented system. This difference in speed is also observed in Nashta, where a single definite article is in use, while demonstratives present traces of an old ternary system 'distal / proximal / unmarked'. In the same way, Standard Bulgarian has a two-term demonstrative system, the - $t$ - suffix being used either as proximal (when contrasted) or as unmarked as far as distance is concerned, while the $-n$ - suffix indicates distance. On the other hand, Standard Macedonian presents the same tripartite system in the demonstratives as in the definite articles.

Mladenova (2007: 318) also signals this lack of symmetry in deixis between the articles and the pronominal and adverbial systems in her account of dialects (the so called mixed systems).

\subsubsection{Demonstratives in Pomak1}


Demonstratives in Pomak1 also follow the double deictic system depending on the space and time. They have both exophoric and endophoric uses. The demonstratives have different forms according to the noun's gender and number:

aisvak (m.), aisos (f.), aisva (n.) and aises (m/f.pl.) aiseva (n.pl) for close entities, ainvak (m.), ainos (f.), ainva (n.) and aines (m/f.pl.) aineva (n.pl) for distant entities and for some future, habitual time related to the situation of utterance, or for a moment with no anchoring to the situation of utterance; and aitvak (m.), aitos (f.), aitva (n.) and aites (m/f.pl.) aiteva (n.pl) for entities close to the addressee or for a past moment related to the situation of utterance.

Here are some examples:

'speaker's sphere'

(7)

ais'os je d'ced-va-sa $\quad k^{\prime} o \int t a^{11}$

DEM.S is.3SG grand,father-POSS-DEF.S house

'This (my sphere) is grand-father's house.' (Q, F2, 30, Pmk, Ell, Tur)

'addressee's sphere'

(8) ts'alo aitv'a Se jad'e-S

all DEM.A MOD eat-2SG

'You'll eat all of this (your sphere).' (S, F8, 21, Pmk, Ell, Tur)

\section{'distal'}

(9) ain'os l'elka hi z'oela je b'esbin evr'o

DEM.DIST aunty POSS.3SG.F took.PRF AUX.3SG 5000 euro

'That aunty of hers, she has got 5000 euros.' (S, F5, 15, Pmk, Ell, Tur) 


\section{'past moment in relation to the situation of utterance'}

(10) dve gud'ini napr'es mand'ili-te b'exa tServ'eni
$\begin{array}{llll}\text { two years } & \begin{array}{l}\text { to, the, scarfs- } \\ \text { front }\end{array} & \text { were.3SG red } & \\ \text { DEF.LOC.PAS } & & \\ \text { 'oti } & b^{\prime} e \int e & \text { ait'os } & \text { m'oda-ta } \\ \text { because } & \text { was.3SG } & \text { that.LOC.PAS } & \text { fashion-DEF.LOC.PAS }\end{array}$

'Two years ago, the scarfs were red because that was the fashion.' (Q, F2, 30, Pmk, Ell, Tur)

\subsection{Deictic comparison markers, quantifiers and relatives in Pomak1}

The three deictic suffixes $-s-,-t-,-n-$, are also used within comparison markers (kaks'o / kakt'o / kakn'o "as") and quantifiers (aisolk'os / aitolk'os / ainolk'os "this much", "that much") in a quite productive manner. Note that in other villages of the area, systems differ: for instance kakn'o "as", is also used for 'simultaneous duration' (sharing those two usages with Greek), while it is not attested in my corpus of Pomak1 and $a g^{\prime} a$ is given in questionnaires. Deictic suffixes can also be encountered partially for manner (ais ' $i$ "this way" / ain'i "that way").

Relatives also follow the deictic system according to space and time:

\section{'addressee's sphere'}

$$
\begin{aligned}
& \text { gjusl'ut } \int \mathrm{i} \text {-te } \overline{3}^{\prime} \text { o-te } \quad \text { n'osi-S par'atika sa } \\
& \text { glasses-DEF.A which-DEF.A wear-2SG ugly are } \\
& \text { 'The glasses that you wear are ugly.' (Q, F5, 15, Pmk, Ell, Tur) }
\end{aligned}
$$




\title{
'speaker's sphere'
}

\section{'past moment in relation to the moment of utterance'}

\author{
(13) \\ gju3l'ut $\int i-t e$ \\ $3^{\prime} \propto-t e$ \\ $n^{\prime}$ osex $\quad \operatorname{lan}^{\prime} i \quad b^{\prime}$ exa \\ gulj'ami \\ glasses-DEF.LOC.PAS which-DEF.LOC.PAS wore.1SG last,year were.3PL big \\ 'The glasses that I wore last year were big.' (Q, F5, 15, Pmk, Ell, Tur) \\ 'future moment in relation to the moment of utterance'

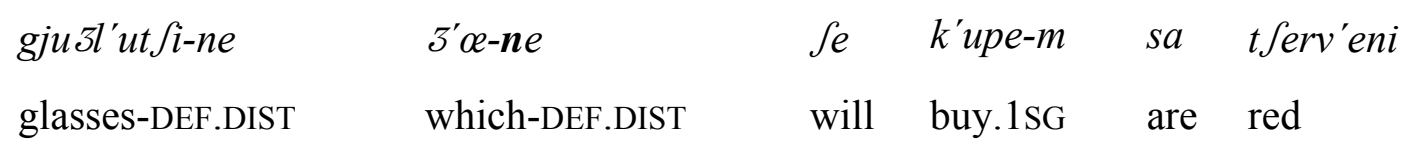 \\ 'The glasses that I will buy are red.' (Q, F5, 15, Pmk, Ell, Tur)
}

\section{Subordinate clauses}

\subsection{Subordinate clauses in the South Slavic languages}

According to Cyxun (1981) and Mladenova (2007), the use of the particle -to in relative pronouns and conjunctions is an innovation, characterizing the Eastern South Slavic area: the Rhodopean dialects are the "centre of innovation in regards to the introduction of overt definiteness" (Mladenova 2007: 243). In this perspective, the uses of the deictics as described in this paper should also be viewed as innovative for South Slavic.

Indeed, conjunctions with -to, deriving from the demonstrative, are found relatively late in the written sources. Analyzing the damaskin ${ }^{12}$ texts, Mladenova (2007: 242) signals a 
split between uses with or without -to for relative pronouns and conjunctions; the relative deto being the most frequent. Concerning the temporal conjunctions, she notes $96.88 \%$ uses of koga and a single use of kogato "when"; the latter being nowadays used in Standard Bulgarian. In Standard Macedonian, despite the use of a ternary definite and demonstrative system, there is no use of deictic suffixes in the temporals as the one observed in Pomak1; the speakers of the standard language use the temporal conjunction koga "when".

\subsection{Subordinate clauses in Pomak1}

Together with the Slavic subordinators, many loans from Greek and Turkish are used in Pomak1. Subordinating conjunctions are indeed high in the borrowability hierarchy in language contact settings (Matras 1998, 2007). In Pomak, some result from old contact, and are well integrated in the language (as Greek oti "because"), while some result from recent contact (as Turkish tam "just as"), and thus are unstable and in competition with Slavic markers.

We will now focus on temporal subordinators based on these deictic suffixes.

\subsubsection{Deixis in temporal subordinate clauses}

In Pomak1 temporal subordinators combine reference to the situation of utterance and reference to the situation of the process through the use of the deictic suffixes as follows ${ }^{13}$ :

1/ Presence of a deictic suffix indicates the anchoring of the utterance to the situation of utterance: ag'a-to, g'ato or kug'ato "when (past)", ag'a-no g'ano or kug'ano "when (future), whenever". Absence of deictics indicates absence of anchoring to the situation of utterance $\left(a g^{\prime} a\right)$. Thus, the temporal marker with no deictic suffix is used for folk tales, jokes 
and other narratives, fictional or not. $A g^{\prime} a$ seems to be taking over some conditional uses, too, while the form $g a$ is specialized for causal usage.

2/ The choice of the deictic suffix indicates the relation between the situation of the process and the situation of utterance.

The 'addressee's' - $t$ - suffix, in $a g^{\prime} a$-to, is used for a 'past' event in relation to the situation of utterance. The 'distal' $-n$ - suffix, in $a g^{\prime} a-n o$, refers to a generic or habitual timeframe and future reference.

Table 4. The temporal subordinating conjunctions in Pomak1

\begin{tabular}{lll}
\hline$a g^{\prime} a$ & "when" & no anchoring to the situation of utterance $(24,25,26)$ \\
(conditional) (34)
\end{tabular}

The interclausal relation is determined both by the subordinators and the TMA markers (on the importance of the complex TMA system in adverbial clauses in Bulgarian, see among others Fielder 1985, Guentchéva 1995).

Note that the three temporal markers presented above are not specialized in a specific type of temporal interclausal relation: for example $a g^{\prime}$ ato is used for anteriority, posteriority, simultaneity, terminus a quo, while all three markers can express anteriority (for this terminology see Kortmann 1997).

To describe the system of Pomak1's temporal subordinators, I shall be using the terminology developed by Culioli (1971, 1978, and 1990) about the notion of situational anchoring, relating the situation of utterance (Sit0) to the situation of the process (Sit2), and applied by Robert (2006: 170) to the study of deixis and subordination in Wolof. Culioli has defined 
three types of relations between Sit0 and Sit2, often, but not uniquely expressed by TMA markers: the situation of the process may be different $(\neq)$ from the situation of utterance, towards being identical $(=)$ to it, or have no relation to it $(\omega)$.

Pomak1 temporal conjunctions express those relations as follows:

\section{Situation of utterance and situation of process are different: Sit $2 \neq$ Sit0}

When the space-time frame of the denoted situation (Sit2) is different from the space-time of the utterance (Sit0), Pomak1 uses the deictic suffixes $-n$ - and $-t$ - to form the temporal subordinators. The -t- suffix, 'close to the addressee', is used for the 'past' in relation to the situation of utterance, while the 'distal' $-n$ - suffix is used for 'habitual' and 'future' events in relation to the situation of utterance.

-to : 'past moment related to the moment of utterance'

$$
\text { ag'a-to fprch besta-ta izgorj'ala }
$$

when-LOC.PAS arrived.1SG house-DEF.LOC.PAS AUX.3SG burned,down.P.PRF 'When I arrived, the house was burned down.'

(On a past event) (Q, F8, 21, Pmk, Ell, Tur)

(16) kug'a-to be dufl'ala n'iki jed'a mer'enda pasut'o when-LOC.PAS AUX.3SG came.P.PRF Niki ate.3SG Merenda ice,cream 'When Niki came, she ate a Merenda ice-cream.'

(On a past event) (Q, F5, 15, Pmk, Ell, Tur) 
ag'a-to b'ese lan'i ait'us im'ase kr'opa k'osa when-LOC.PAS were.2SG last,year here had.2SG short hair 'When you were here last year, you had short hair.'

(On a past event) (Q, F2, 30, Pmk, Ell, Tur)

\section{-no : 'habitual, generic, future moment related to the time of utterance'}

$\begin{array}{llll}\boldsymbol{a g}^{\prime} \boldsymbol{a} \text {-no } & \text { st'anva } & s f^{\prime} a d b a \\ \text { when-LOC.HAB.FUT } & \text { happen.3SG } & \text { marriage } \\ \text { zb'ira } & \text { sa } & \text { ts'alo } & \text { s'elo-so }^{\prime} \\ \text { gather.3SG } & \text { REFL } & \text { all } & \text { village-DEF.S }\end{array}$

'Whenever there is a marriage, the whole (of my) village gathers.' (On local traditions) (Q, F8, 21, Pmk, Ell, Tur)

(19) ag'a-no umr'e bunn'o ni pr'ave-t v'olta when-LOC.HAB.FUT die.3SG someone NEG make-3PL walk 'Whenever someone dies, they don't take a walk ${ }^{15}$.' (On local traditions) (Q, F2, 30, Pmk, E1l, Tur)

(20) ag'a-no d'ojde nj'akuf politik'os when-LOC.HAB.FUT come.3SG some politician fSe d'ava nj'akvo 'erso always give-3SG some public,work 'Whenever a politician comes, he always offers some public work'. 
(Conversation about politicians and their politics about the villages)

(Q, F2, 30, Pmk, Ell, Tur)

Below some examples of the use of $a g^{\prime} a-n o / k u g^{\prime} a-n o$ for future events:

(21) kug'a-no d'ojde $\quad$ Se $[h] i \quad$ gu onesa-m

when-LOC.HAB.FUT come.3SG MOD 3SG.F.DAT 3SG.M/N.ACC bring-1SG

'When she comes, I'll bring it to her.'

(The speaker has a gift to give to a friend who is not at the village at the moment)

(S, F5, 15, Pmk, Ell, Tur)

(22)

ag'a-no mi punarast'o-t m'ufka det'i-se

when-LOC.HAB.FUT 1SG.DAT grow,up-3PL a,little children-DEF.S

Se d'ojde-me nah par'isi

MOD come-1PL to Paris

'When the (my) children grow up a little, we'll come to Paris.'

(Future plans) (Q, F2, 30, Pmk, Ell, Tur)

(23)

ag'a-no fprje-s na plat'ia-na

when-LOC.HAB.FUT arrive-2SG at square-DEF.DIST

f'ati nah lj'avana str'ana

seaze.IMP.2SG to left side

'When you arrive at the central square, take the left side.' 
(Instructions in order to locate a place in the village) (Q, F8, 21, Pmk, Ell, Tur)

The choice of the temporal subordinator in Pomak1 doesn't depend on the TMA choice, even though some TMA are more frequent for a given subordinator, since it relates to a past or future event. The following examples illustrate that: in 24 and 25 the speaker gives two possible versions, changing the TMA markers while maintaining the temporal subordinator ag'ano.

$\begin{array}{llllll}\boldsymbol{a g} \boldsymbol{g}^{\prime a-n o} & \text { ima } & s f^{\prime} \text { adba } & \text { zb'ira } & s a & \text { s'elo } \\ \text { when-LOC.HAB.FUT } & \text { have.3SG } & \text { marriage } & \text { gather.3SG } & \text { REFL } & \text { village }\end{array}$

'Whenever there is a marriage, the whole of the village gathers.'

(On local traditions) (Q, F2, 30, Pmk, Ell, Tur)

(25)

ag'a-no imalo sf'adba

when-LOC.HAB.FUT AUX.3SG have.PRF marriage

zb'iralo $\quad s a \quad$ s $\quad$ s'elo

gather.PRF REFL AUX.3SG village

'Whenever there was a marriage, the whole of the village gathered.'

(On local traditions) (Q, F2, 30, Pmk, Ell, Tur)

Also see the examples 15 and 16 illustrating the fact that the subordinator's choice is not determined by the TMA.

\section{No anchoring of the situation of process in the situation of utterance: Sit2 $\omega$ Sit0}

When there is a break between the space-time of the process and the space-time of the utterance, Pomak1 does not use deictic suffixes, but the free subordinator $a g^{\prime} a\left(k u g^{\prime} a\right.$ is not 
attested in such use). In this case, the process is not anchored in relation to the utterance. This subordinator is almost exclusively used in fictional narratives and tales (the habitual $a g^{\prime}$ ano subordinator is very seldom encountered):

ag'a sa v'ornal-i dve gud'ini sj'etne ud alam'anie when REFL return.EVID-3PL two years after from Germany

utifl'il-i da plat'a-t jajts'a-na

go.EVID-3PL to pay-3PL eggs-DEF.DIST

'When they returned, two years later from Germany, they went to pay the eggs.'

(Nasradin joke) (S, M3, 70, Pmk, Ell, Tur)

(27)

ag'a utifl'il-i po udv'ode sr'eftal-i m'ajka mu when go.EVID-3PL more out meet.EVID-3PL mother POSS3SG.M 'When they went a little further, they met his mother.'

(Nasradin joke) (S, M3, 70, Pmk, Ell, Tur)

(28)

\begin{tabular}{|c|c|c|c|c|c|}
\hline$a g^{\prime} a$ & je & fprj'ala & je & razv'orzala & $t \int u v^{\prime} a l-a n$ \\
\hline when & AUX.3SG & arrived.PRF & AUX.3SG & untied.PRF & bag-DEF.DIST \\
\hline
\end{tabular}

The constant use of $a g^{\prime} a$ in tales is also confirmed by other corpus of the area, such as the tales published in Theoharidis (1995) ${ }^{16}$ and Kokkas (2004b). 


\section{Identification between the two situations: Sit2 = Sit0}

When the space-time of the denoted situation is identified with the space-time of the utterance, Pomak1 could, in theory, use the 'proximal to the speaker' deictic suffix $-s-$, but in practice no such usages were attested during my fieldwork. When asked, the Pomak1 speakers say they cannot use $a g^{\prime}$ aso. An educated speaker from another village of the area thought this was a logical possibility, making a clear parallel with the threefold definite system, but still had difficulties in producing any such examples. Still, in the Rhodope dialects in Bulgaria, gasu seems to be still in use (p.c. Kanevska-Nikolova).

\subsubsection{Deixis and immediate anteriority}

Immediate anteriority is also marked differently according to the type of discursive anchoring. Immediate anteriority is expressed by prefixing $l i$ to $a g^{\prime} a$ (becoming $g a$ ) for situations with no anchoring to speech time, to kug'ano for a future event related to the situation of utterance or for some habitual event, and to kug'ato for past events.

Table 5: Immediate anteriority subordinating conjunctions in Pomak1

\begin{tabular}{|c|c|c|}
\hline liga & "as soon as" & $\begin{array}{l}\text { immediate anteriority in a moment } \\
\text { with no anchoring to the situation of utterance }\end{array}$ \\
\hline li kug'ato & "as soon as" & $\begin{array}{l}\text { immediate anteriority in a past moment } \\
\text { in relation to the situation of utterance }\end{array}$ \\
\hline$l i$ & "as soon as" & immediate anteriority in future moment \\
\hline kug'ano & & or habitual event with relation to the situation of utterance \\
\hline
\end{tabular}

As an adverb $l i$ in Pomak1 means: 
1) 'immediately', e.g. li r'ipnala 'she hopped immediately';

2) 'all the time, constantly', e.g. li r'uka 'she was calling all the time'.

$L i$ is also a yes-no interrogative particle, as was already the case in Old Church Slavonic, and as commonly found in many other Slavic languages (there have been many studies on the meaning and placement of $l i$ in Slavic languages). Example in Pomak1:

h'ubeve li ste? 'Are you OK?'

j'ala li si? 'Have you eaten?'

In Bulgarian, $l i$ is used as a subordinator with a meaning close to the conditional (Guentchéva 1995).

Below some examples of immediate anteriority in Pomak1:

li kug'ato 'immediate anteriority-past'

\begin{tabular}{|c|c|c|c|}
\hline li-kug'a-to & $g u$ & r'ekah- & $\operatorname{stan}^{\prime} a$ \\
\hline & & me & \\
\hline immediately-when- & 3SG.M/N.ACC & said-1PL & became. $3 \mathrm{SG}$ \\
\hline
\end{tabular}

'As soon as we said it, it happened'. (S, F2, 30, Pmk, Ell, Tur)

\section{li kug'ano 'immediate anteriority-future/habitual'}

\begin{tabular}{|c|c|c|c|c|}
\hline li-kug'a-no & $s a$ & razbud'i-S & $z^{\prime} \propto[m i]$ & telef'on \\
\hline immediately-when- & REFL & wake,up- & take.IMP.2SG & 1SG.ACC telephone \\
\hline LOC.HAB.FUT & & $2 \mathrm{SG}$ & & \\
\hline
\end{tabular}

'As soon as you wake up, call me.' (Q, F2, 30, Pmk, Ell, Tur) 


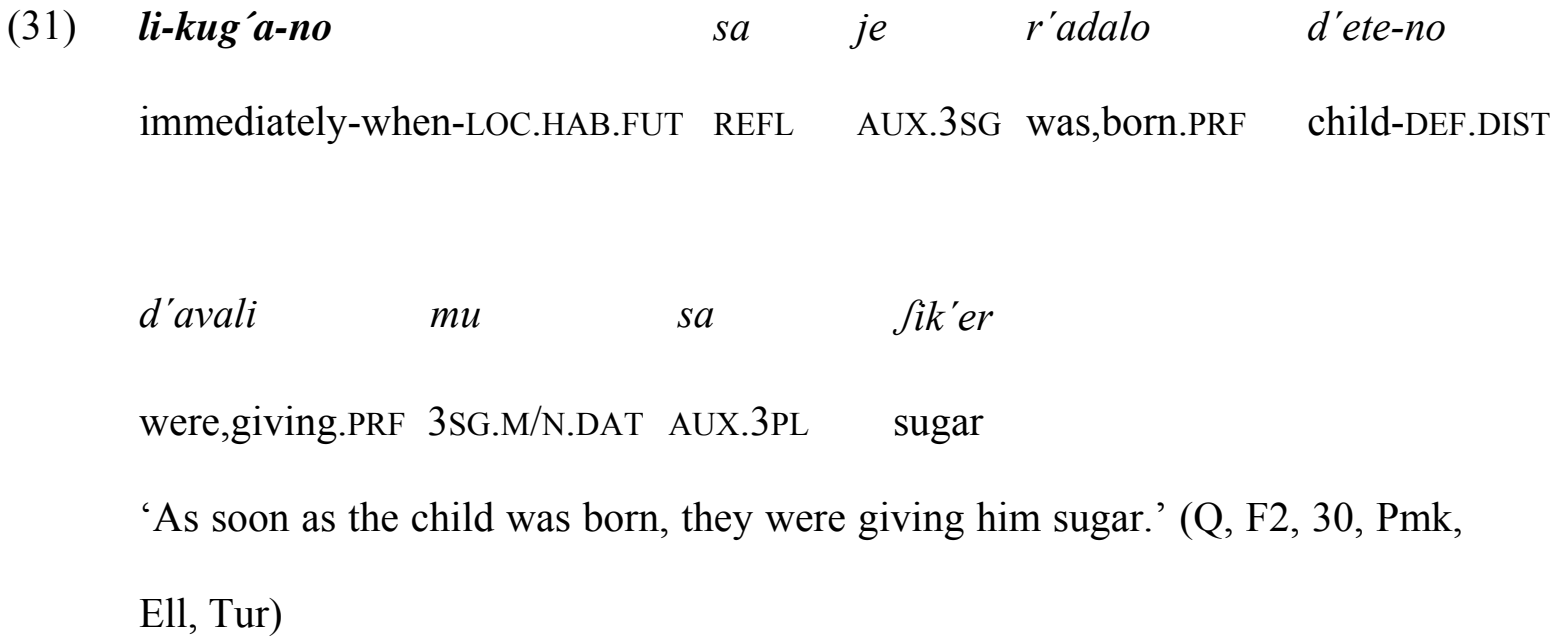

\section{tam 'immediate anteriority, past moment related to the moment of utterance' \\ tam (from Turkish) 'just as, as soon as ${ }^{, 17}$, is external to the native system relative to the time of utterance. Thus, language contact, first through loan, but then finally through conceptual pressure in case of stable contact situation, might trigger the change of the Pomak system of temporal conjunctions.}

\begin{tabular}{|c|c|c|c|c|}
\hline tam & fprceh & isk'et $\int e \quad z \propto$ & $m a$ & telef'on \\
\hline just,as & arrived.1SG in & Isketshe took.3SG & 1SG.ACC & telephone \\
\hline
\end{tabular}

\section{Polyfunctionality}

Some of the adverbial subordinators presented above are polyfunctional.

\subsection{Conditionals}




\section{$A g$ 'a : from 'temporal' to 'hypothetical'}

It is very common cross-linguistically for temporal subordinators to express conditional or hypothetical meanings (Traugott 1986). In Pomak1, $a g^{\prime} a$, also has a hypothetical meaning, even though the most frequent subordinator is $a k^{\prime} u$.

$$
\text { ni p'oje-m n'ema da 'ida-m faf panepist'imjo }
$$

ag'a $^{\prime}$

if NEG study-1SG not,have.3SG to go-1SG in university

'If I don't study, I won't go to the university.' (Q, F3, 7, Pmk, Ell)

\section{$a k^{\prime} u$ 'conditional'}

This is the most frequent conditional subordinator in Pomak1, used for both realis and irrealis clauses.

$\boldsymbol{a k}^{\prime} \mathbf{u}$ 'ifta-t da 'ida-t da sa utf'o-t faf panepist'imjo-no
if want- to go-3PL to REFL study-3PL in university-
3PL

tr'aeva da 'ima-t h'ubavi kit'ape ut dimotik'o-no must.3SG to have-3PL good books from primary-DEF.DIST

'If they want to go to study to the University, they must have good books since the primary school.' (Q, F2, 30, Pmk, Ell, Tur)

(35)
ak'u ne r'aboti
$t \int y l j j^{\prime}$ cek-an
$m i$
if
NEG work.3SG
husband-DEF.DIST POSS.1SG 
Se da d'ojda nah s'elo

MOD MOD come.3SG to village

'If my husband doesn't work, he will come to the village.'

(Q, F2, 30, Pmk, Ell, Tur)

(36)

ak'u beh zn'ala

if $\quad$ AUX.1SG knew.P.PRF

Se beh rud'ila dr'ugo-no d'ete po napr'es MOD AUX.1SG gave,birth.P.PRF another-DEF.DIST child more to, the,front 'If I had known, I would have had another child earlier.' (Q, F2, 30, Pmk, Ell, Tur)

\subsection{Causal}

\section{Ga: from 'temporal' to 'causal'}

It is also common cross-linguistically for temporal subordinators to express causality. In Pomak1, ga also has some causal uses, most probably derived from the temporal $a g^{\prime} a$ after phonetic erosion. The use of ga presents the cause-effect relation as obvious and has a strong discursive component. The causal clause with ga usually precedes the main clause.

$$
\begin{array}{llllll}
\text { ga } & \text { n'ema-me tumaf'il } n i & \text { h'ode-me } & \text { nah } & \text { den'iz-en } \\
\text { since not,have-1PL car } & \text { NEG } & \text { go-1PL to } & \text { sea-DEF.DIST }
\end{array}
$$

'Since we don't have a car, we won't go to the sea.' (Q, F2, 30, Pmk, E1l, Tur) 


$$
\begin{array}{lllll}
\text { ga } & \text { ni } & \text { Ste- } \int \quad \text { n'ema } & d a & \text { h'ode-me } \\
\text { since NEG } & \text { want-2SG not,have.3SG to } & \text { go-1 PL } \\
\text { 'Since you don't want, we won't go.' (Q, F2, 30, Pmk, Ell, Tur) }
\end{array}
$$

\section{'oti: causal}

The other causal subordinator 'oti, is probably a loan from New Testament Greek 'oti 'because'. In the causal clauses with 'oti, the main clause generally precedes the subordinate clause.
(39)
ait'us
tr'ceva $\quad d a$
je
let'alo
here
must.3SG to
AUX.3SG
rained.PRF
'oti
sab'alahin
be
j'atse
m'okro
p'ot-en
because in,the,morning was.3SG a,lot
wet
street-DEF.DIST
'Here, it must have rained because this morning the street was wet.'
(S, F8, 21, Pmk, Ell, Tur)
(40)
$g u$
ni ist'ce
'oti v'ika gjo
je par'atik
NEG wanted.3SG because say.3SG supposedly is.3SG ugly
3SG.M/N.ACC
'She didn't want him because, she says, supposedly he's ugly.' (S, F5, 15, Pmk, Ell, Tur)
(41) k'opel-an hi je dal sind3'ir boy-DEF.DIST 3SG.F.DAT AUX.3SG gave.PRF necklace 'oti j im'ala du'omgyny 


\section{AUX.3SG had.PRF birthday}

because

'The boy offered her a necklace because it was her birthday.' (S, F5, 15, Pmk, Ell, Tur)

\section{Conclusion}

The study of the Pomak variety spoken in the Xanthi area (Greece) reveals an interesting use of deixis in the formation of temporal subordinators, indicating the anchoring of the event to the time of utterance while the choice of the subordinator indicates the type of event encoded in the clause. Absence of a deictic suffix indicates the break between the situation of utterance and the situation of the process.

This is an uncommon phenomenon among Slavic languages, even though a more common one cross-linguistically as shown in this volume. More research needs to be done, both in a synchronic and diachronic perspective, on this phenomenon that has received practically no attention in South Slavic studies. 


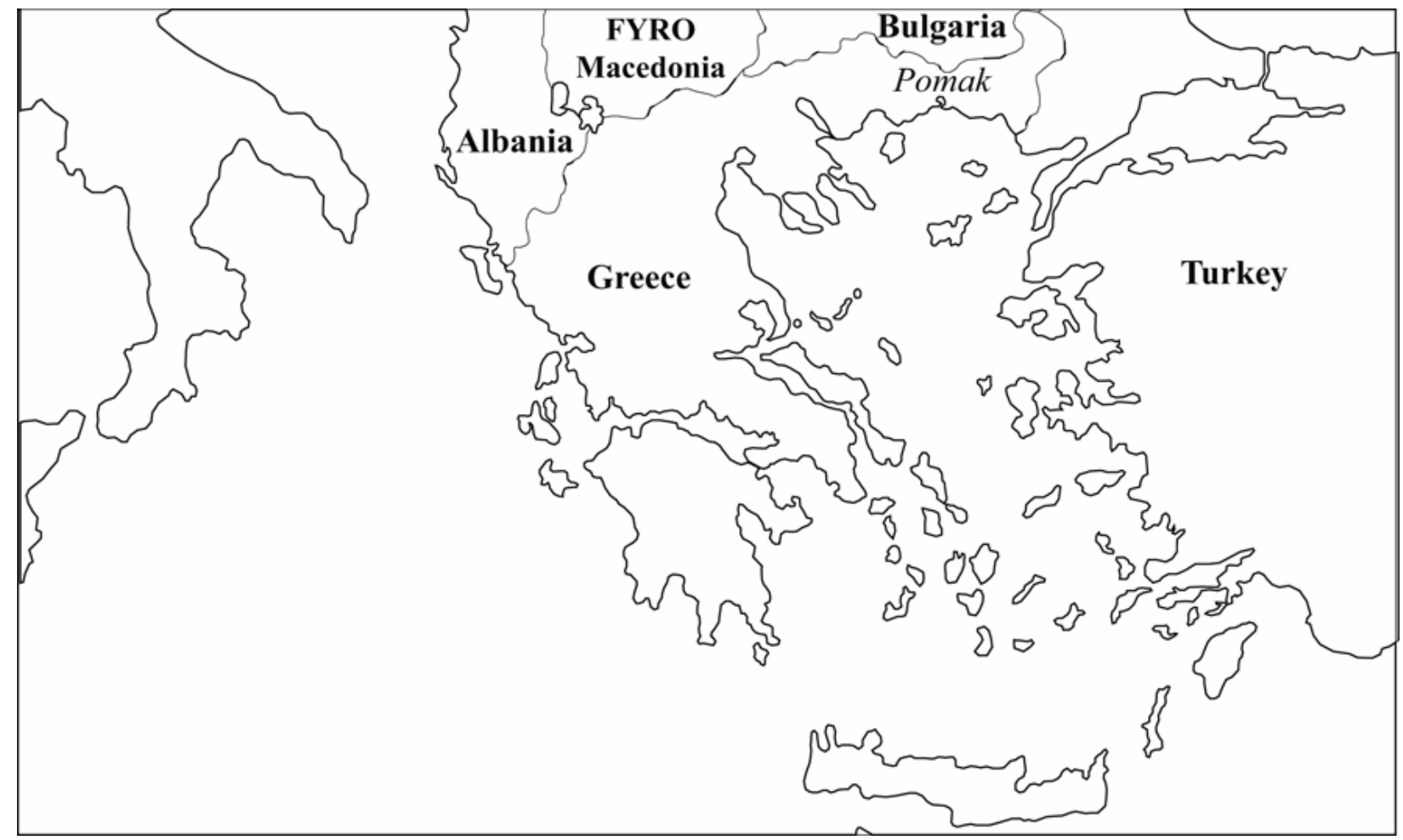

\begin{abstract}
Abbreviations
ACC - accusative; AUX - auxiliary; DAT - dative; DEF.A - definite addressee's sphere; DEF.DIST definite distal; DEF.S - definite speaker's sphere; EVID - evidential; F - female; GEN - genitive; ELL - Greek; IMP - imperative; LOC.HAB.FUT - located in the habitual/future of the moment of utterance; LOC.PAS - located in the past of the moment of utterance; M - male; MOD modality; N - neutral; NEG - negation; POSS - possessive; PRF - perfect; P.PRF - past perfect; PMK - Pomak; Q - questionnaire; REFL - reflexive; S - spontaneous; TMA - Time, Mood, Aspect; TUR Turkish
\end{abstract}

\title{
References
}

Adamou, E. 2006. Le nashta. Description d'un parler slave de Grèce en voie de disparition. Muenchen: Lincom. 
— 2008. Sur les traces d'une dégrammaticalisation : le médiatif en pomaque (Grèce). Revue des Etudes Slaves: Proceedings of the French delegation at the XIV International Congress of Slavists 78(1-2): 177-189.

Adamou, E. \& Drettas, G. 2008. Slave. In Le patrimoine plurilingue de la Grèce, E. Adamou (ed.), 107-132. Leuven: Peeters.

Anderson, S. R. \& Keenan, E. L. 1985. Deixis. In Language, Typology and Syntactic Description, Shopen T. (ed.), 259-308. Cambridge: Cambridge University Press.

Asenova, P. 2002 [1st edition 1989]. Balkansko ezikoznanie. Veliko Tŭrnovo: Faber.

Bally, C. 1926. L'expression des idées de la sphère personnelle et de solidarité dans les langues indo-européennes. In Festschrift Louis Gauchat, Fankhauser F. \& J. Jakob (eds), 68-78. Aarau: Verlag Sauerlander.

Breu, W. 1994. Der Faktor Sprachkontakt in einer dynamischen Typologie des Slavischen. In Slavistische Linguistik 1993, Mehlig H. R. (ed.), 41-64. Muenchen: Verlag Otto Sagner.

Bril, I. 2002. Le nêlêmwa (Nouvelle-Calédonie) : Analyse syntaxique et sémantique. LouvainParis : Peeters.

Culioli, A. 1971. À propos d'opérations intervenant dans le traitement formel des langues naturelles. Mathématiques et Sciences humaines 34: 7-15.

- 1978 [1983]. Valeurs aspectuelles et opérations énonciatives : la notion d'aoristique. In Enonciation: Aspect et détermination, S. Fisher \& J. J. Franckel (eds.), 99-114. Paris: EHESS.

- 1990. Pour une linguistique de l'énonciation. Opérations et représentations. Paris/Gap: Ophrys.

Cyxun, G. A. 1981. Tipologičeskie problemy balkanoslavjanskogo jazykovogo areala. Minsk: Nauka i texnika. 
Dimitrova-Vulchanova, M. \& Vulchanov, V. In press. An Article Evolving. In DIGS Volume, Anderson, S. \& Jonas, D. (eds). Oxford: Oxford University Press.

Drettas, G. 1990. Le dialecte bulgaro-macédonien de Xr. (Edhessa, Grèce). Questions de typologie. Bulletin de la Société de Linguistique de Paris 85 (1): 227-265.

Elson, M.J. 1976. The definite article in Bulgarian and Macedonian. Slavic and East European Journal 20: 273-9.

Feuillet, J. 1999. Grammaire historique du bulgare. Paris: Institut d'études slaves.

Fielder, G. E. 1985. Aspect and Modality in Bulgarian subordinate clauses. In The scope of Slavic aspect, M. Flier \& A. Timberlake (eds), 181-193. Columbus, OH: Slavica.

Friedman, V. 2002. Macedonian. Muenchen: Lincom.

- 2004. The typology of Balkan evidentiality and areal linguistics. In Balkan syntax and semantics, O. Tomic (ed.), 101-134. Amsterdam: Benjamins.

Guentchéva, Z. 1995. L’imparfait perfectif en bulgare. Modèles linguistiques 16(2): 73-94.

Gălăbov, I. 1950. Za člena v bălgarskija ezik. Izvestija na narodnija muzej v Burgas 1: 171227.

Kabasanov, S. 1963. Edin starinen bălgarski govor. Tixomirskijat govor. Sofia: Izd. na Bălgarskata akademija na naukite.

Kasatkina, R. 2008. Artikli, predartikli i psevdoartikli v russkom iazyke. In Proccedings of the Russian delegation at the XIVe International Congress of Slavists, 305-321.

Kanevska-Nikolova, E. 2001. Govorăt na selo Momčilovci, Smoljensko - polovin vek pokăsno. Sofia: Meždunarodno sociolingvističesko družestvo.

- 2006. Trojnoto členuvane v rodopskite govori. Plovdiv: Univ. Izdatelstvo Paisij Xilendarski.

Kokkas, N. 2004a. Uchem so Pomatsko. Xanthi : Pakethra.

- 2004b. Uchem so Pomatsko B. Texts. Xanthi : Pakethra. 
Kortmann, B. 1997. Adverbial Subordination: A typology and history of adverbial subordinators. Berlin, New York: Mouton de Gruyter.

Levinson, S. 2004. Deixis and pragmatics. In The Handbook of pragmatics, L. Horn \& G. Ward (eds.), 97-121. Oxford: Blackwell.

Lyons, C. 1999. Definitiness. Cambridge: Cambridge University Press.

Marchello-Nizia, C. 2006. From personal deixis to spatial deixis. In Space in languages: linguistic systems and cognitive categories, M. Hickmann \& S. Robert (eds), 103-120. Amsterdam/Philadelphia: John Benjamins.

Matras, Y. 1998. Utterance modifiers and universals of grammatical borrowing. Linguistics 36(2): 281-331.

- 2007. The borrowability of structural categories. In Grammatical borrowing in crosslinguistic perspective, Matras Y.\& J. Sakel (eds), 31-73. Berlin: Mouton de Gruyter.

Minova-Gurkova, L. (ed.). 1997. Makedonski jazik. Skopje: Prosvetno delo.

Mirčev, K. 1964. Za člennite formi v srednobălgarskite pametnici. Izvestija na Instituta za Bălgarski Ezik 11: 231-234.

Mladenov, M. 1990. Ima li v bălgarskija ezik dvojno členuvane? Bălgarski ezik 40/30: 229231.

Mladenova, O. 2007. Definiteness in Bulgarian. Berlin, New York: Mouton de Gruyter.

Robert, S. 2006. Deictic space in Wolof. In Space in languages: linguistic systems and cognitive categories, M. Hickmann \& S. Robert (eds), 155-174. Amsterdam/Philadelphia: John Benjamins.

Rogo, A. 2002. Pomakika dhimotika tragoudhia tis Thrakis. Xanthi: Tameion Thrakis. Theoharidis, P. 1995. Pomakoi. Xanthi: Pakethra.

- 1996a. Grammatiki tis Pomakikis glossas. Thessaloniki: Aigeiros.

- 1996b. Ellino-Pomakiko lexiko. Thessaloniki: Aigeiros. 
- 1996c. Pomako-Elliniko lexiko. Thessaloniki: Aigeiros.

Sobolev, A. N. 2001. Bolgarskij shirokolykskij govor: Sintaksis, Leksika duchovnoj kul'tury, Teksty. Marburg: Biblion Verlag.

Svane, G. 1961-62. O sintaksičeskom primenenii bolgarskogo člena v XIII veke. A. Čergedskie teksty. B. Dobrejšovo evangelie. Scando-Slavica 7, 8: 233-51, 24-8.

Topolinjska, Z. 2006. Trojnot člen: da ili ne? Juznoslovenski filolog 62: 7-15.

Traugott, E., Ter Meulen, A. \& Reilly, J. \& Ferguson, C. A. (eds) 1986. On conditionals. Cambridge: Cambridge University Press.

Vaillant, A. 1964. Manuel du vieux slave. Paris: Institut d'études slaves.

- 1977. Grammaire comparée des langues slaves. Tome V. Paris: Institut d'études slaves. 
* I wish to thank Isabelle Bril and Stéphane Robert; their work and comments were fundamental for the comprehension of the Pomak temporal subordinators. I also thank Zlatka Guentchéva and the two anonymous readers for their useful remarks.

${ }^{1}$ Similar spatio-temporal uses are observed cross-linguistically, see for example the case of Nêlêmwa in Bril (2002).

${ }^{2}$ Fieldwork was conducted in 2005, 2006, 2007 and 2009 by the author with the financial support of the laboratory LACITO, CNRS, France.

${ }^{3}$ Given the political pressure on Pomak speakers, within a context of linguistic shift to Turkish, I decided not to mention the villages' names, despite the obvious interest this would present in a dialectological perspective. Pomak1 stands for the village of the Xanthi area and Pomak2 for the village of the Evros area. I sincerely thank the speakers who accepted to participate in this study.

${ }^{4}$ Old Church Slavonic [OCS] refers to the eldest available Slavic documents, mostly ecclesiastical. OCS extends from the 9th to the 11th century and is classified as South Slavic.

5 The distinction between 'Bulgarian' and 'Macedonian' dialects depends on the authors and their ideological background. Bulgarian linguists have long considered the whole of the South Slavic varieties as 'Bulgarian' dialects, despite variation and important structural differences; the demarcation line being with Serbian. Since the standardization of Macedonian, and reinforced by the creation of an independent Republic, the term 'Macedonian' has slowly made its way to the international bibliography. Within this context, where linguistics are linked with politics, we choose to apply the term 'Bulgarian dialects' for the varieties situated 
in Bulgaria, 'Macedonian dialects' for those in FYROMacedonia - even though for Macedonian linguists, the 'Macedonian' dialects go beyond these borders (in Albania, Bulgaria, Greece, Kosovo). For the denomination of Slavic in Greece see Adamou \& Drettas 2008

Moreover, the terms 'language' and 'dialect' are in this context highly connected to political and ideological factors. Therefore, we use 'varieties' as a linguistic term for oral tradition languages seen in their diversity. Nevertheless, it is obvious that from a linguistic point of view those South Slavic standard languages and non-standard varieties are closely related and are part of the same linguistic diasystem.

${ }^{6}$ In Greece, in a village of the Evros area, the system has been reduced to the $-t$ - definite, while possessive uses of the $-s$ - article occur occasionally. I consider this change to be a loss; the speakers in their metalinguistic comments mention three articles, which are not found in their oral productions.

${ }^{7}$ Indefinite nouns have no articles; they may be preceded by the numeral 'one' which is not a fully grammaticalized indefinite article.

${ }^{8}$ There are many loan words from both Greek and Turkish in Pomak1. I do not signal their origin, the Pomak morphology and syntax being respected in most cases.

${ }^{9}$ Each example is followed by a description of the context. I systematically signal if the example is spontaneous (S), for data recorded or not, or extracted by questionnaire (Q). The questionnaire consists in translating from Greek a sentence that was usually produced in Pomak by a speaker, in natural speech, but that I didn't have the chance to record. 
The speaker's gender (male M, female F) is followed by an identification number valid for this paper. Are also noted the age and the languages spoken by the consultant: Pmk stands for Pomak, Ell for Greek and Tur for Turkish. All data were collected between 2005-2007 by the author.

${ }^{10} i z i$ (m.), isáy (f.), izí, isáy (n.) and iséy (pl.) for close entities, inazí (m.), ináy (f.), inazí, ináy (n.) and inéy (pl.) for distant entities.

${ }^{11}$ Note that the vowels /o/, /e/, /a/ when accentuated are diphthongized [u'o], [j'e], [j'a], and, when not accentuated, are reduced.

${ }^{12}$ Translated literary texts of a religious and didactic nature, in what is referred to as Modern and for some of them Middle Bulgarian (17th-18th century).

13 This is not a unified analysis for all the Rhodope varieties using deixis in the temporal conjunctions. Observations based on short term fieldwork in a Pomak variety in the Evros department in Greece, show a different system whose understanding requires further research (fieldwork notes Adamou 2005-2006). Moreover, a quick look on data from Siroka Laka (Bulgaria) in Sobolev (2001), doesn't seem to corroborate the uses observed in Pomak1, even though deictic suffixes are very frequently used with temporal subordinators. It would be interesting, among others, to compare with Kabasanov's description of Tixomir (1963), a Rhodope variety in Bulgaria, very close to the Greek border, spoken by Muslims.

${ }^{14}$ Variation between $k u g^{\prime} a$-no/to (based on the interrogative $k u g^{\prime} a$ ) and $a g^{\prime} a$-no/to (based on the temporal subordinator $a g^{\prime} a$ ) depends on the speaker's age and possibly his education; 
older speakers, or younger ones with little education, seem to prefer $a g^{\prime} a$-, although I have not conducted any precise sociolinguistic study on this topic. In any case, both forms are accepted by the speakers when asked.

15 This term refers to a special social event that takes place in the afternoon, when unmarried girls walk in the main village street in front of the boys in order to make a potential match. This walk takes place in two villages of the area and gathers young people from the surrounding villages.

${ }^{16}$ In this corpus, segmentation is not always accurate, sometimes including the auxiliary 'be' or the reflexive.

${ }^{17}$ tamam 'at the same time' and li tamam 'as soon as', are known to be used in Pomak but did not figure in our corpus. Tamam is also used in Macedonian and Bulgarian. 